\title{
Entre a sedução e a desconfiança: o jogo do autor e do leitor em Les Faux-Monnayeurs de André Gide
}

\author{
Isabelle Santos Bezerra ${ }^{1}$
}

RESUMO: O presente artigo visa a uma análise dos papéis do autor e do leitor na obra de André Gide, Les faux-monnayeurs. Por meio da discussão de alguns aspectos referentes aos estudos autobiográficos, às reflexões da estética da recepção e da teoria mimética de René Girard, propõe-se uma reflexão acerca da relação que pode haver entre um leitor ativo e o escritor. Além disso, propõe-se analisar de que forma a impressão de um relato autobiográfico permite uma reconfiguração da relação entre leitor e autor, gerando a possibilidade do estabelecimento entre eles de uma relação mimética.

PALAVRAS-CHAVE: André Gide, Les faux-monnayeurs, leitura, teoria mimética.

ABSTRACT: This article presents an analysis of the author and reader's roles in the work of André Gide, The Counterfeiters (Les faux-monnayeurs). Through the discussion of some questions concerning the autobiographical studies, the reflections of Aesthetic of Reception critical school and René Girard's mimetic theory, we engage in a reflection about the relationship between an active reader and the writer. In addition, we propose to analyze how the autobiographical perception of the book allows a reconfiguration of the relationship between the reader and the author, in order to show how this approach may result in a mimetic relationship.

KEY WORDS: André Gide, Les faux-monnayeurs, reading process, mimetic theory.

RÉSUMÉ: Cet article a pour but d'analyser les rôles de l'auteur et du lecteur dans l'oeuvre d'André Gide, Les faux-monnayeurs moyennant la discussion de certains aspects concernant les études autobiographiques, les réflexions de l'esthétique de la réception et ceux de la théorie mimétique de René Girard. D’ailleurs, on veut analyser la façon dont l'impression d'un récit autobiographique permet une reconfiguration de la rélation entre le lecteur et l'auteur, ce qui permettrait la possibilité d'établir entre eux une rélation mimétique.

MOTS CLÉS: André Gide, Les faux-monnayeurs, lecture,théorie mimétique.

E, embora à primeira vista a leitura possa não parecer um ato de criação, é-o num sentido profundo. Sem o leitor apaixonado, que, na realidade, é o complemento do autor e muitas vezes o seu mais secreto rival, um livro morreria. O homem que passa a palavra aumenta não só a vida do livro em questão, mas o próprio ato de criação.

(Henry Miller, Os livros da minha vida)

"Em suma, este caderno em que escrevo a própria história do livro, eu o vejo todo vertido no livro, formando o interesse principal, para maior irritação do leitor" (GIDE, 2009a, p. 60). Essa passagem do Diário dos Moedeiros Falsos, de André Gide, aponta para uma preocupação central do autor: a busca por um leitor ativo que reconstrua a obra durante o processo de leitura.

\footnotetext{
${ }^{1}$ Graduanda em Letras pela Universidade de São Paulo - São Paulo. Realiza pesquisa de iniciação cien-
} tífica sob orientação da Prof ํㅡa Verónica Galíndez-Jorge. Contato: isabelle.bzr@me.com. 
Em seu primeiro e único romance, Os moedeiros falsos, André Gide não esconde seu anseio por um leitor participativo. É interessante observar como a obra, escrita em 1925, ainda é de grande interesse para o leitor contemporâneo, suscitando questionamentos acerca da relação entre biografia e ficção. Em meio a uma narrativa construída a partir de diversos pontos de vista, diálogos, monólogos, intervenções do narrador, e entremeada por cartas e bilhetes, técnicas como a mise en abyme ${ }^{2}$ e a presença do Diário de Édouard atiçam o leitor curioso, levando-o a se questionar sobre o estatuto ficcional da obra e confundindo-o acerca dos limites entre criação ficcional e criação autobiográfica.

Gide tinha como um de seus objetivos instigar seu leitor, convidando-o para o jogo da ficção. Durante a composição de seu "primeiro romance", o autor decidiu manter e publicar um diário no qual relatava o processo de criação da obra, que resultou em Diário dos moedeiros falsos. A respeito do Diário, não podemos nos esquecer da aproximação entre as reflexões do próprio autor, contidas neste diário, às de Édouard, personagem-romancista, inseridas no romance. Tal efeito fica evidente quando lemos o seguinte trecho do romance, em que Édouard diz:

Trabalho de maneira curiosa, que vou lhes descrever: num caderno, anoto dia a dia a evolução desse romance em minha mente; sim, é uma espécie de diário que mantenho, como faria uma criança... Quer dizer que no lugar de contentar-me com resolver, à medida que aparece, cada dificuldade (e toda obra de arte não é senão a soma ou o produto das soluções de uma quantidade de pequenas dificuldades sucessivas), cada uma dessas dificuldades eu exponho e estudo. Se quiserem, esse caderno contém a crítica de meu romance; ou melhor: do romance em geral. Imaginem o interesse que teria para nós semelhante caderno mantido por Dickens, ou Balzac; se tivéssemos o diário de $A$ educação sentimental ou dos Irmãos Karamázov! A história da obra, de sua gestação! Seria arrebatador... mais interessante do que a própria obra... (GIDE, 2009b, p. 207)

Essa temática do diário de criação é, portanto, trabalhada duplamente: temos o diário de criação de Gide e o trabalho de criação de Édouard. O recurso da mise en abyme,

A mise en abyme consiste em inserir em uma narrativa o próprio assunto da obra. Segundo GOULET (1991, p. 125) “c'est Gide qui, en 1893, avait lance dans son Journal cette expression, empruntée à l’héraldique, appellée à connaître une grande célébrité. Elle qualifiait le fait de transposer, 'à l'échelle des personnages le sujet même de l'œuvre”.

Na dedicatória do romance lemos “À Roger Martin Du Gard je dédie mon premier roman en témoignage d’amitié profonde”. Apesar de ter publicado diversos escritos anteriormente, Gide os classificava como "récits" ou "sorties".

1 “J’y travaille d'une façon três curieuse, que je m'en vais vous dire: sur un carnet, je note au jour le jour l'état de ce roman dans mon esprit ; oui, c'est une sorte de journal que je tiens, comme on ferait celui d'un enfant... C'est-à-dire qu'au lieu de me contenter de résoudre, à mesure qu'elle se propose, chaque difficulté (et toute œuvre d'art n'est que la somme ou le produit des solutions d'une quantité de menues difficultés successives), chacune de ces difficultés, je l'expose, je l'étudie. Si vous voulez, ce carnet contient la critique de mon roman ; ou mieux: du roman en général. Songez à l’intérêt qu'aurait pour nous un semblable carnet tenu par Dickens, ou Balzac ; si nous avions le journal de L'Éducation Sentimentale, ou des Frères Karamazov ! l'histoire de l'oeuvre, de sa gestation ! Mais ce serait passionnant...plus intéressant que l'œuvre elle-même..." (GIDE, 1934, p. 207-08). 
como pudemos ver na passagem acima, permite que o leitor coloque essas duas obras em relação, potencializando o efeito perturbador devido à aproximação dessas duas leituras. Assim, evidencia-se o papel do criador por trás da obra, de maneira que o leitor volta a sua atenção para a figura do autor.

O fato de Gide publicar seu caderno de criação e, assim, tornar acessível ao leitor comum o diário no qual relata a gênese do romance não deixou de ser uma inovação. $O$ interesse que pode ter uma obra como essa pode advir, nos dias de hoje, de uma simples constatação: o mito em torno do escritor e o interesse por sua obra e vida.

Não apenas a literatura moderna tem se caracterizado pelo interesse crescente nas questões concernentes ao processo de composição da obra, como também vemos uma grande curiosidade do público leitor acerca dessas questões. No Brasil, festivais literários como a Festa Literária Internacional de Paraty (FLIP), que reuniu cerca de 25 mil pessoas em sua edição de 2012, têm atraído escritores de diversas partes do mundo e um público que não se restringe mais a escritores, acadêmicos e jornalistas, mas a pessoas comuns que, por meio da leitura, se sentem mais próximas do autor e da obra. Orhan Pamuk (2012, p. 31) nota que um dos principais prazeres proporcionados por um romance consiste no questionamento que fazemos acerca da relação entre experiências concretas e fictícias contidas na obra. Diz ele que

outro prazer relacionado é o que nos oferece a leitura do que os romancistas dizem em seu prefácio, nas sobrecapas, nas entrevistas e nas memórias, quando tentam nos convencer de que suas experiências da vida real são produto de sua imaginação ou que suas narrativas inventadas são histórias verdadeiras. (PAMUK, 2012, p. 31)

No mesmo sentido, Manguel nota que

nas leituras de autores, em festivais de escritores em Toronto, Edimburgo, Melbourne ou Salamanca, os leitores esperam tornar-se parte do processo artístico. O inesperado, o não ensaiado, o evento que se revelará de alguma forma inesquecível, poderá, esperam eles, acontecer diante de seus olhos, tornando-os testemunhas de um momento de criação - uma felicidade negada até a Adão. (MANGUEL, 2010, p. 291)

Vê-se, pois, a atualidade de um romance como Os moedeiros falsos, no qual o processo de criação é assunto mesmo da obra e permeia sua própria forma, bem como do diário, que dá acesso à table de travail do escritor. O leitor transforma-se assim em cúmplice de uma criação que, embora aparentemente acabada, requer sua participação para sua plena significação. Em parte, esse efeito sobre o leitor torna-se possível devido justamente às reflexões sobre a escrita às quais Gide submete seu leitor.

O presente artigo pretende, por meio da aproximação entre o romance e o diário de Os moedeiros falsos, estabelecer uma reflexão inicial sobre a importância do leitor para a compreensão desse romance gideano e algumas implicações possíveis na relação autor-leitor que podem decorrer dessa abordagem. É, afinal, levantando indícios e questionando os dados contidos no romance que o leitor será levado a se questionar 
sobre os limites entre ficção e realidade dentro do romance e do próprio diário, adotando assim uma atitude de desconfiança que percorrerá toda a sua leitura. A curiosidade do leitor acerca da possibilidade de uma relação entre personagem e autor, vida e obra, acaba levando-o a ter como foco a escritura e a figura do autor. Deixando cair a máscara da ficção, há na escrita do romance certa teatralidade, que não deixa o leitor se esquecer de que aquilo que ele lê não passa de uma criação ficcional, colocando, assim, a construção da obra - e o escritor por trás dela - em foco. Essa "teatralidade" fica evidente em um capítulo central do romance, no qual o narrador julga seus personagens.

Segundo GOULET (1991, p. 135) temos Gide, o autor real que assina o romance e que publica seu diário com suas considerações sobre o processo de composição da obra e assim "alimenta [o romance] de observações pessoais e de elementos autobiográficos mais ou menos transformados", há o "autor abstrato ou narrador implícito" que organiza o conjunto de narrativas que constituirá a obra final que o leitor lê e, finalmente, há um "narrador explícito" que diz "eu" e "nós" e que, de acordo com Goulet, é uma "presença que circula como uma sombra no interior do universo ficcional". É este narrador explícito, segundo a definição de Goulet, que vai até mesmo julgar seus personagens ${ }^{5}$. Essa complexidade narrativa ajuda a romper a todo o momento o horizonte de expectativas do leitor, que deve estar sempre atento ao desenrolar do romance.

É possível notar essa distinção entre os narradores conforme propõe Goulet por meio de algumas passagens do romance. Como exemplo de "autor abstrato / narrador implícito", há passagens que nos remetem a uma focalização semelhante a uma câmera de cinema ou a um roteiro teatral:

Robert está escrevendo. Está sentado diante de uma escrivaninha coberta de livros. Diante dela, a porta-janela que dá para o jardim está escancarada ao luar. Fala sem se voltar. (GIDE, 2009b, p. 49)

Tira da mala a caderneta. Do bolso, tira uma caneta. Escreve [...]. (GIDE, 2009b, p. 83)

Consulta seu relógio. Onze e trinta e cinco. Já deveria ter chegado. (GIDE, 2009b, p. 85)

Em relação ao “narrador explícito”, podemos verificar os seguintes exemplos:

O pai e o filho não têm mais nada a se dizer. Deixemo-los. Logo serão onze horas. Deixemos a senhora Profitendieu em seu quarto sentada numa cadeira reta pouco confortável. (GIDE, 2009b, p. 33)

[...] Não pretendo insinuar que não teria sido capaz de voltar a Paris especialmente para socorrer Laura; digo que ficou feliz por voltar. (GIDE, 2009b, p. 78)

Passemos adiante. Tudo o que disse acima foi só para arejar um pouco as páginas deste diário. Agora que Bernard respirou bem, voltemos a ele. Ei-lo mergulhado novamente na leitura. (GIDE, 2009b, p. 127)

O viajante, ao chegar ao alto da colina, senta-se e olha antes de retomar a marcha, agora declinante; procura distinguir aonde o conduz afinal esse caminho sinuoso que

5 Trata-se do capítulo VII, intitulado "O autor julga suas personagens", da segunda parte do romance - Saas-Fée.
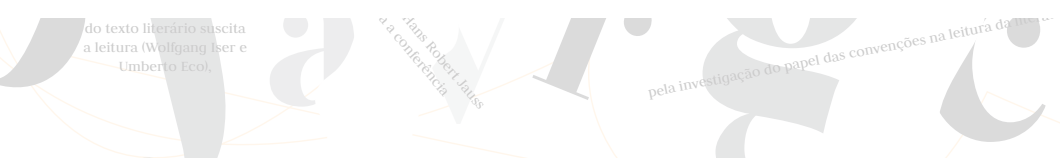
tomou, que parece perder-se na sombra e, uma vez que cai a tarde, na noite. Assim o autor imprevidente estaca por um instante, retoma fôlego, e se pergunta com inquietação aonde vai levá-lo sua narrativa. Temo que, entregando o pequeno Boris aos Azaïs, Édouard cometa uma imprudência. (GIDE, 2009b, p.239)

No último caso, o leitor, que antes estava habituado às reflexões feitas por Édouard por meio de seu diário, é confrontado então por julgamentos e reflexões sucessivos sobre a escrita feitos em uma primeira pessoa que não remete à Édouard. Esse narrador em primeira pessoa contribui, consequentemente, para denunciar a construção ficcional por trás do romance.

Importante lembrarmos que a obra de André Gide surge em meio à chamada "crise do romance", pautada na recusa do gênero realista. Essa preocupação estará presente nas reflexões do personagem-escritor Édouard e na própria estrutura do romance, em que temos essa constante ruptura do contrato ficcional. A partir de então, o papel do leitor não se resumirá ao de um "espectador" guiado pelo narrador, no qual se deve confiar de olhos fechados. Ainda que o leitor de Gide se encontre em diversos momentos em uma situação de completo voyeurismo, ele irá inevitavelmente se questionar sobre o estatuto ficcional dessa obra, que traz diversas rupturas em relação aos romances "realistas" que o precederam.

Até que ponto o autor tem autoridade sobre sua obra e qual o papel do leitor para sua construção são questões que têm envolvido críticos, filósofos, autores e também leitores. Manguel (2010, p. 112) lembra, por exemplo, que Kafka, autor de diversos escritos não terminados, acreditava que o inacabamento da obra concedia espaço para o leitor. Diz ele que "não existe a última página de $O$ Castelo, porque, K., o herói, jamais deve chegar lá, de tal forma que o leitor continue o texto de múltiplas camadas para sempre".

Assim como Kafka via na obra espaço para o trabalho do leitor, Gide adota uma postura semelhante ao deixar ao seu leitor a possibilidade de ler o romance conjuntamente com o diário no qual diz relatar o processo de criação da obra.

Devemos recordar, também, que o projeto de Édouard, a escrita de um romance chamado Os moedeiros falsos, não chega a ser concluído, tendo o leitor acesso apenas às reflexões anotadas em seu diário e um único capítulo no qual Édouard ficcionaliza um acontecimento "real", passagem em que ele utiliza a ficção como maneira de alertar o personagem Georges Molinier acerca de sua conduta ${ }^{6}$. Nesse caso, mais do que um “inacabamento", podemos falar que não há a obra como realização, mas há, no entanto, a obra como um projeto de cujo desenvolvimento o leitor é cúmplice.

Dessa forma, Gide incita seu leitor a se posicionar de modo participativo frente à leitura do romance, como podemos ler no seguinte trecho de seu Diário: “[...] Depois, terminado o livro, eu largo o leme, e entrego ao leitor o cuidado da operação; adição, subtração, pouco importa; estimo que não cabe a mim fazê-la. Tanto pior para o leitor preguiçoso: quero outros. Preocupar, é esse meu papel"’ (GIDE, 2009a, p. 111).

${ }^{6}$ Referimo-nos à passagem contida no capítulo XV da terceira parte do romance.

7 “Puis, mon livre achevé, je tire la barre, et laisse au lecteur le soin de l’opération ; addition, soustraction, peu importe: j'estime que ce n'est pas à moi de la faire. Tant pis pour le lecteur paresseux: j'en veux d’autres. Inquiéter, tel est mon rôle” (GIDE, 1934, p. 94). 


\section{O leitor desconfiado}

O filósofo Paul Ricoeur (2010, p. 269) sustenta que "é somente pela mediação da leitura que a obra literária obtém a significância completa”. No caso do romance gideano, o leitor é a via para que o texto possa adquirir múltiplas significâncias, um dos aspectos pelo qual mantém sua atualidade para o leitor de hoje.

Pode-se dizer que os estudos teóricos dedicados à leitura e ao papel do leitor firmaram-se após o surgimento da estética da recepção, em 1967, ano em que Hans Robert Jauss proferiu sua aula inaugural na Universidade de Constança, intitulada "A história da literatura como provocação à ciência da literatura".

Para Jauss (1979), a atividade comunicativa é o momento mediador da experiência estética, que deve ser estudada partindo-se da relação entre produção (autor), comunicação (texto) e recepção (leitor). A partir dos estudos de Hans Robert Jauss e Wolfgang Iser, a leitura seria estudada sob duas perspectivas: como ato individual e como ato coletivo, ambos submetidos ao horizonte de expectativas - ou repertório - do leitor. A partir de então, um dos desdobramentos de tal enfoque, na teoria e crítica literária, permitiu que se passasse a considerar a leitura como uma espécie de recriação da obra literária.

Compagnon observa alguns pressupostos gerais da estética da recepção:

Como em Ingarden, o texto literário é caracterizado por sua incompletude e a literatura se realiza na leitura. A literatura tem, pois, uma existência dupla e heterogênea. Ela existe independentemente da leitura, nos textos e nas bibliotecas em potencial, por assim dizer, mas ela se concretiza somente na leitura. O objeto literário autêntico é a própria interação do texto com o leitor. (COMPAGNON, 2010, p. 147)

Como observa Ricoeur (2010, p. 285-86) acerca dos teóricos da recepção, as investigações de Wolfgang Iser procuram analisar "o efeito produzido sobre o leitor individual e sua resposta no processo de leitura" ao passo que as reflexões Jauss centram-se na "resposta do público ao nível de suas expectativas coletivas"; mas esclarece que:

Essas duas estéticas podem parecer opostas, na medida em que uma tende para uma psicologia fenomenológica e a segunda visa reformar a história literária. Na verdade, elas se pressupõem mutuamente: por um lado, é através do processo individual de leitura que o texto revela sua 'estrutura de apelo'; por outro, é na medida em que o leitor participa das expectativas sedimentadas no público que ele é constituído em leitor competente; o ato de leitura torna-se assim um elo na história da recepção de uma obra pelo público. (RICOEUR, 2010, p. 286)

O teórico Iser defende que o texto é caracterizado por conter certo grau de indeterminação. Para ele, "os lugares vazios, em suma, apresentam a estrutura do texto literário como uma articulação com furos, que exige do leitor mais do que a capacidade de decodificação. A decodificação diz respeito ao domínio da língua. O vazio exige do leitor uma participação ativa" (apud JAUSS, 1979, p. 26). 
É justamente uma participação ativa que Gide esperava de seus leitores, como nota em seu Diário dos moedeiros falsos. Esse anseio é descrito em diversas passagens do Diário:

Fui levado, enquanto escrevia, a pensar que a intimidade, a penetração, a investigação psicológica pode, sob alguns aspectos, ser levada mais adiante no "romance" até do que nas confissões. [...] Gostaria que os acontecimentos nunca fossem contados diretamente pelo autor, mas de preferência expostos (e várias vezes, sob ângulos diversos) por aqueles dos atores sobre quem esses acontecimentos tiverem tido alguma influência. Gostaria que, na narrativa que os atores fizerem, tais acontecimentos apareçam ligeiramente deformados; uma espécie de interesse vem, para o leitor, do simples fato de que ele tem de restabelecer. A história requer sua colaboração para bem delinear-se. (GIDE, 2009a, p. 37-38)

Convém [...] deixar o leitor sentir-se em vantagem sobre mim - agir de maneira a permitir-lhe acreditar que é mais inteligente do que o autor, mais moral, mais perspicaz e que descobre nas personagens muitas coisas, e no decurso da narrativa muitas verdades, a despeito do autor e, por assim dizer, à sua revelia. (GIDE, 2009a, p. 81-82)

Como vemos nas passagens acima, as reflexões de Gide vão ao encontro do que defende Jauss (1979, p. 102-103) ao dizer que "o observador pode considerar o objeto estético como incompleto, sair de sua atitude contemplativa e converter-se em (co)criador da obra, à medida que conclui a concretização de sua forma e de seu significado".

Com isso, é possível perceber o papel central que pode ter a leitura na própria construção do romance. Fala-se, pois, de co-criação ou re-criação do romance, já que, segundo o romancista, a participação do leitor é requisito para o bom delineamento da obra. É nesse ponto que a impressão de um relato autobiográfico ${ }^{8}$ se encontra diretamente ligada a essa postura ativa do leitor: a forma que Gide encontrará para imergir o leitor nas questões sobre o romance e a ficção será rompendo constantemente seu horizonte de expectativas, por meio de suas reflexões, mas sobretudo devido à maneira como constrói a narrativa. Em parte, pode-se dizer que o Diário de Édouard, inserido no romance, tem papel fundamental para a produção desse efeito, já que contém as principais reflexões sobre o processo de criação de uma obra, levando o leitor a questionar a convergência entre as reflexões de Édouard e as de Gide presentes no Diário dos moedeiros falsos. O que nos interessa nessa possível "convergência" é o efeito perturbador e questionador sobre o leitor. A semelhança entre a passagem do "roubo do livro", contida no diário de Gide e "ficcionalizada" no diário de Édouard, por exemplo, não passa dispercebida a um leitor atento e contribui para esse interesse acerca da escritura e da figura do autor enquanto escritor.

Fala-se de "impressão de um relato autobiográfico" já que não se trata de proceder a uma verificação acerca da veracidade de certas passagens do romance em relação à biografia do autor, mas sim do efeito produzido por essas passagens no leitor. Em outras palavras, o que importa é a simples possibilidade de o leitor, confundido pela construção ficcional que exige sua participação, ser assim levado a considerar a possibilidade de um relato de fundo autobiográfico.

9 Trata-se de passagem do dia 3 de maio, contida no Diário dos Moedeiros Falsos e "ficcionalizada" no romance na passagem do diário de Édouard, presente no capítulo 11 da primeira parte. 
A leitura do romance e do diário mostra que Gide voltava sua atenção conscientemente para o leitor. Ele sabia que seu papel principal consistia em envolvê-lo nesse jogo ficcional, frustrando-o a cada novo capítulo, pretendendo, assim, gerar novos questionamentos e reflexões ${ }^{10}$. A complexidade narrativa da obra faz com que o leitor se sinta impelido a levantar indícios, procurar brechas, questionar o narrador e seu próprio papel como leitor.

Gide confessa em seu diário: "Este [romance] terminará bruscamente, não por esgotamento do assunto, que deve dar a impressão de ser inesgotável, mas, ao contrário, por seu alargamento e por uma espécie de evasão de seu contorno. Ele não deve se fechar, mas espalhar-se, desfazer-se..."II (GIDE, 2009a, p. 106).

A esse respeito, é oportuna a seguinte observação que faz Ricoeur:

O ato de leitura tende a se tornar, com o romance moderno, uma réplica à estratégia de decepção tão bem ilustrada por Ulisses de Joyce. Essa estratégia consiste em frustrar a expectativa de uma configuração imediatamente legível. E em colocar nas costas do leitor a tarefa de configurar a obra. [...] o leitor moderno corre o risco de vergar sob o fardo de uma tarefa impossível, quando lhe pedem para suprir a falta de legibilidade maquinada pelo autor. A leitura torna-se esse piquenique em que o autor traz as palavras e o leitor a significação. (RICOEUR, 2010, p. 289)

Essa "estratégia de decepção" pode ter uma contrapartida no que se refere à "reação" do leitor, que poderá ser um leitor ativo, mas também desconfiado:

A afirmação de que o autor cria seus leitores parece carecer de uma contrapartida dialética. Talvez seja função da literatura mais corrosiva contribuir para fazer aparecer um leitor de um novo tipo, um leitor ele mesmo desconfiado, porque a leitura deixa de ser uma viagem tranquila feita em companhia de um narrador digno de confiança, e se torna um combate com o autor implicado, um combate que o reconduz a si mesmo. (RICOEUR, 2010, 279)

É possível depreender que, ao decepcionar seu leitor quebrando constantemente seu horizonte de expectativas, Gide permitirá a configuração de um leitor desconfiado. Soma-se a isso o fato do leitor contar com o Diário dos moedeiros falsos, que faz com que o leitor passe a questionar seu próprio papel, tendo em vista que depara em diversos momentos com os "desejos" de Gide por um leitor participativo.

\footnotetext{
${ }^{10}$ Em seu Diário dos moedeiros falsos, Gide (2009a, [1934], p. 95) diz que "cada novo capítulo deve levantar um novo problema, ser uma abertura, uma direção, um impulso, um lançamento para frente - da mente do leitor". No original: "chaque nouveau chapitre doit poser un nouveau problème, être une ouverture, une direction, une impulsion, une jetée en avant - de l'esprit du lecteur”.

"[Ce roman] "s'achèvera brusquement, non point par épuisement du sujet, qui doit donner l'impression de l'inépuisable, mais au contraire, par son élargissement et par une sorte d'évasion de son contour. Il ne doit pas se boucler, mais s'éparpiller, se défaire”.
} 
O crítico Roland Barthes, em seu texto sobre Gide e seu Diário, atenta para o interesse moderno acerca do processo de criação da obra e sobre a consciência do escritor acerca do poder de sua obra e de seu leitor:

Romances de Gide - Notar que o lado habitual do romance (observações, atmosfera, psicologia) é silenciado. Tudo isso é considerado coisa sabida. O romance foi escrito além, a partir da trama ordinária; tem confiança na qualidade do leitor.

Nossa época, em alguns de seus maiores escritores (na verdade, desde Edgar A. Poe), poderia ser definida pelo fato de que o artista desmonta os procedimentos da criação e interessa-se por eles quase tanto quanto por sua obra. Porque acabou de entender que a arte é um jogo, uma técnica (isso data do dia em que os franceses inventaram a fórmula da Arte pela Arte). Não acredito que esteja interpretando erroneamente Valéry, ao dizer que ele se tornou poeta para poder dar conta exata dos procedimentos da poética. Donde o surpreendente Diário de Édouard e, também, vários trechos do Diário. (BARTHES, 2004, p. 21)

No caso de Gide, é possível dizer que, ao saciar o interesse do leitor pelo processo de escrita da obra, tornando acessível seu diário de criação, ele atiça ainda mais sua curiosidade, levando-o a se questionar sobre seu próprio papel para a construção da obra. $O$ leitor sente então que, para que ele possa de fato compreender o romance, deve partir em busca de detalhes perdidos, de relações que extrapolam uma simples leitura desinteressada. Mas como vimos, a atitude do leitor de Gide não é mais a de um leitor ingênuo, e sim de um leitor desconfiado. Aos olhos do leitor, as reflexões de Gide guardam uma curiosa semelhança com as de Édouard e um leitor um pouco mais interessado pela figura do autor poderia até se questionar acerca de algumas aproximações entre personagens e passagens do romance e acontecimentos da vida do autor ${ }^{12}$.

Ao abrir a possibilidade, por meio da construção de seu romance, de um questionamento da relação entre ficção e realidade, o leitor passa a se questionar sobre possíveis elementos autobiográficos na obra. Esse efeito é inegavelmente potencializado pela técnica da mise en abyme e a presença do Diário de Édouard. Hubier nota que "la lecture d'un journal ou d'un carnet est presque inévitablement autobiographique et le lecteur reconstruit à son gré un sens que le texte n’indiquait point” (2005, p. 125). Mas

${ }^{12}$ Não deixa de ser curioso que algumas edições, como a edição francesa utilizada para este estudo, insira notas de rodapé que explicam ao leitor algumas "convergências" entre passagens do romance e a vida de Gide, como é o caso do início do capítulo XI da primeira parte, em que o leitor lê a seguinte passagem de Édouard: “Je revenais au matin de chez Perrin, où j’allais surveiller le servisse de presse pour la réédition de mon vieux livre” (GIDE, 2009c, p. 95-6). Reproduzo a seguir a nota presente na referida edição, que remete ao nome "Perrin”: “[Perrinn] Éditeur de la fin du XIX siècle. Il publia Les Cahiers d’André Walter, le premier ouvrage de Gide. Ce dernier, mécontent de la qualité de l'édition, la retira de la vente e la confia à Edmond Bailly, propriétaire indépendant de la Librairie de l'Art”. Trata-se de uma edição comentada (texto integral + "dossier") do romance de Gide, o que explicaria a presença de notas referentes a uma contextualização histórica ou literária, mas não biográfica. É, portanto, sintomático que a própria edição faça essas aproximações para o leitor. Contudo, como dissemos anteriormente, não pretendemos proceder nem explicitar possíveis aproximações entre a vida e obra de André Gide. Trata-se, sobretudo, de tentar mostrar que a simples impressão dessa relação constitui o próprio movimento operador da narrativa, além de voltar a atenção do leitor para o que é nosso foco no presente estudo: sua relação, enquanto leitor, com a figura do autor/escritor. 
Gide não deixa respostas ao seu leitor, já que demonstra seu desejo por uma obra que, pelo ato de leitura, se desfaça, se espalhe em direção a novas compreensões. A partir desse questionamento, opera-se uma nova possibilidade diante do leitor, que pode estabelecer então uma relação pessoal com a obra.

Sabe-se que muitas vezes o que leva o leitor a se interessar por uma obra é a busca de algo que apenas o escritor pode dar, seja o alívio de suas angústias, o compartilhamento de paixões, uma resposta a questões de seu tempo ou, ainda, o contato com um mundo que só o artista pode fornecer. Sob esse ponto de vista, o autor está desde o início em uma posição privilegiada em relação ao seu leitor. Como nota Ricoeur, "é do autor que parte a estratégia de persuasão que tem o leitor como alvo. É a essa estratégia de persuasão que o leitor responde acompanhando a configuração e se apropriando da proposição de mundo do texto" (2010, p. 271).

Gide, em Os moedeiros falsos, estabelece com o leitor um jogo ficcional e o leitor, ao aceitar participar desse jogo por meio da leitura, começa a levantar indícios e a estabelecer relações que serão mediadas pela imagem que ele aos poucos constrói do autor. Como a relação é mediada pela figura do autor, que "seduz" o leitor, este estará condicionado, de certa forma, à imagem que o escritor deseja passar de si mesmo.

Em um romance como Madame Bovary, Emma, como leitora, lê querendo copiar suas heroínas românticas. Em Gide, o leitor lê querendo copiar seu autor. Ele é levado a ter o autor como foco, já que passa a crer em uma possível relação entre o personagem-romancista, Édouard, e a vida do escritor. O jogo ficcional que Gide cria coloca-o como uma presença “fantasma" constante na obra, já que o leitor do romance está sempre se questionando sobre a relação entre o caráter ficcional e autobiográfico desta. O narrador que, como vimos, constantemente "relembra" o leitor de que está lendo uma obra construída intencionalmente daquela maneira, contribui para a quebra do contrato realista. Em um romance como Madame Bovary, a narração onisciente contribui para um distanciamento da figura do autor. Em uma obra como Os moedeiros falsos, o autor se torna uma figura fortemente presente, já que torna central a reflexão sobre o processo de criação, o qual, por sua vez, torna a figura do escritor o centro das atenções.

Como dissemos anteriormente, a desconfiança do leitor em relação às semelhanças entre as reflexões de Gide e de seu personagem-escritor, levam-no a um questionamento maior, sob uma chave autobiográfica, que poderá reconfigurar sua leitura do romance.

Há, em Os moedeiros falsos, passagens que mais lançam questionamentos ao leitor do que se prestam à resolução de questões internas. É o caso de passagens - todas reflexões do personagem Édouard, seja por meio de diálogos seja através de trechos de seu diário - como as que seguem:

Será difícil, em Os moedeiros falsos, fazer com que se admita que quem representar a minha personagem tenha podido, embora permanecendo em boas relações com a irmã, não conhecer os filhos dela. Sempre tive a maior dificuldade para maquiar a verdade. (GIDE, 2009b, p. 99)

O que me preocupa é sentir a vida (minha vida) separar-se aqui de minha obra, minha obra apartar-se de minha vida. (GIDE, 2009b, p. 101) 
- Aguardo que a realidade me dite o conteúdo.

- Mas eu achava que o senhor queria afastar-se da realidade.

- O meu romancista quererá afastar-se; mas eu vou levá-lo continuamente de volta a ela. A bem dizer, esse será o tema: a luta entre os fatos propostos pela realidade e a realidade ideal. (GIDE, 2009b, p. 206)

O que quero é apresentar de um lado a realidade e de outro lado esse esforço para estilizá-la, do qual eu lhes falava há pouco. [...] Para obter esse efeito, acompanhem-me, invento uma personagem de romancista, que coloco como figura central; e o tema do livro, se quiserem, é precisamente a luta entre o que lhe oferece a realidade e o que ele pretende fazer dela.

- E depois vejo muito bem o que vai acontecer - exclamou Laura - nesse romancista, você só poderá pintar-se a si mesmo. (GIDE, 2009b, p. 205-6)

Tendo o processo de criação e as reflexões teóricas e estéticas de Gide e Édouard em mente, o leitor passará a refletir sobre a escritura em si e sua relação com a vida do autor, com uma realidade exterior à obra.

\section{A sedução do autor}

Em uma obra recente, Literatura em Perigo, Todorov demonstra sua discordância em relação ao que chama de "tendência solipsista" da literatura, referindo-se aos estudos da autobiografia e da autoficção:

[...] a tendência niilista conhece uma exceção maior, que concerne ao fragmento do mundo constituído pelo autor em si. Outra prática literária provém, com efeito, de uma atitude complacente e narcísica que leva o autor a descrever detalhadamente suas menores emoções, suas mais insignificantes experiências sexuais, suas reminiscências mais fúteis: quanto mais repugnante, mais fascinante é o mundo! Falar mal de si, aliás, não destrói esse prazer, já que o essencial é falar de si - o que se diz é secundário. A literatura (nesse caso, diz-se, preferencialmente "a escrita") tornou-se apenas um laboratório no qual o autor pode estudar a si mesmo a seu bel-prazer e tentar se compreender. É possível qualificar essa terceira tendência, após as do formalismo e do niilismo, de solipsismo, de acordo com essa teoria filosófica que postula que o si mesmo é o único ser existente. A falta de verossimilhança dessa teoria, de fato, a condena à marginalidade, mas isso não impede que ela se torne um programa de criação literária. Uma de suas variantes recentes é o que se chama de "autoficção": o autor continua a se dedicar à evocação de seus humores, mas, além disso, se libera de todo constrangimento referencial, beneficiando-se assim tanto da suposta independência da ficção quanto do prazer engendrado pela valorização de si. (TODOROV, 2010, p. 43-44)

É essa postura do autor que Todorov caracteriza como “um prazer da valorização de si”, que pode ser interpretada como o que Diana Klinger, por sua vez, caracterizou como
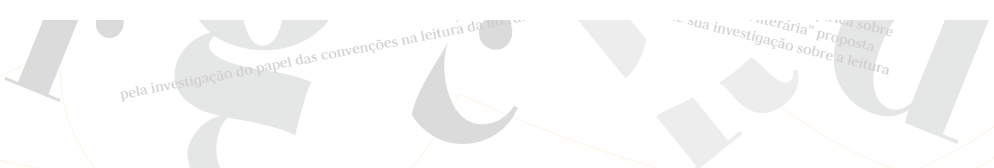
a "performance do autor". Para a autora, "a matéria da autoficção não é a autobiografia, mas sim o mito do escritor" (KLINGER, 2007, p. 51). Sendo assim:

A autoficção é uma máquina produtora de mitos do escritor, que funciona tanto nas passagens em que se relatam vivências do narrador quanto naqueles momentos da narrativa em que o autor introduz no relato uma referência à própria escrita, ou seja, a pergunta pelo lugar da fala (O que é ser escritor? Como é o processo da escrita? Quem diz eu?). (KLINGER, 2007, p 51)

Essa postura do autor de jogar com os limites entre biografia e ficção pode ser vista como uma estratégia de colocar a si próprio em evidência. Essa escolha do autor não seria uma simples tentativa autoficcional de não se comprometer com uma primeira pessoa autobiográfica ${ }^{13}$, mas uma maneira de criar uma determinada imagem de si para o leitor. Essa possibilidade permite uma reconfiguração na forma de vermos o papel do autor. Intimamente ligado a seu leitor, o autor necessita dele para que compactue com a imagem que ele propõe de si ou para que o leitor, ao contrário, estabeleça outra imagem do autor, “à sua revelia”, como desejava André Gide.

As conceituações de Todorov e Klinger podem, ainda, ser entendidas sob o ponto de vista de outro crítico, o francês René Girard. Diz ele que

Imitar o desejo de seu amante é desejar-se a si próprio graças ao desejo desse amante. Essa modalidade particular de mediação dupla se chama coquetismo. [...] A coquete não quer entregar sua preciosa pessoa aos desejos que ela provoca, mas ela não seria tão preciosa se não os provocasse. [...] É por isso que a faceira procura avidamente as provas dessa preferência; ela alimenta e atiça os desejos, não para abandonar-se a eles, mas para a eles melhor recusar-se. O "desespero" do amante e a coqueteria da amada crescem conjuntamente, pois os dois sentimentos são copiados um do outro. É um mesmo desejo, sempre mais intenso, que circula entre os dois parceiros. (GIRARD, 2009, p. 133)

É importante notar que Girard se refere em suas análises sobre personagens de determinados romances e, no caso, o coquetismo seria uma atitude característica de personagens como Albertine, de Em busca do tempo perdido. A reflexão girardiana, no entanto, pode ser vista também como uma atitude do autor em relação a si mesmo que, ao colocar-se como dono do jogo ficcional, detém em última instância a "verdade" sobre os questionamentos do leitor, resultando em uma variação do que Todorov chamou de tendência a uma "valorização de si". Essa atitude, no entanto, não precisa ser vista necessariamente com a desconfiança relatada por Todorov. Como pudemos ver até o

\footnotetext{
13 A autoficção, termo cunhado por Serge Doubrovsky em 1977, é um conceito atualmente sujeito a diversas discussões e tentativas de teorização. O até então neologismo criado por Doubrovsky foi uma tentativa do autor de conceituar seu novo romance, Fils. Nas palavras do autor, a autoficção se torna "une modélisation de l'autobiographie en ce sens où elle est conçue comme une ruse permettant à l'auteur d'échapper aux regards inquisiteurs, aux reproches d'impudeur et d'indiscrétion que pourraient lui faire ses propres “personnages”. Em "L'autofiction: une réception problématique”, disponível em www.fabula. org/forum/colloque99/208.php, acessado em 24/05/2012.
} 
momento, o jogo que se estabelece entre autor e leitor nada tem de inocente. Enquanto o leitor busca desvendar verdades sobre o autor, ansioso por até, quem sabe, descobrir "mentiras", inconsistências, "pegá-lo" em flagrante delito; o autor, por sua vez, consciente de seu trabalho e do poder de sua obra, lança falsos indícios e coloca um pouco de si e de sua vida em diversos personagens, convidando seu leitor à reflexão.

No caso de Gide, é claro o desejo por um leitor participativo e curioso, mas não devemos nos esquecer de que mesmo as reflexões deixadas em seu Diário foram posteriormente publicadas pelo próprio autor. Sendo assim, a emergência de um leitor desconfiado põe em jogo sua relação com o autor e a escrita, já que não se tem mais certeza acerca da confiabilidade de seu autor.

O autor joga com o leitor; logo, essa atitude de valorização de si, por meio do relato de fundo autoficcional, pode ser vista como uma consciência do autor em relação ao Outro. Não é para convencer a si próprio que o autor adota determinada postura, mas sim para se mostrar ao Outro. A esse respeito, Girard diz que "essa dialética do apelo que se nega enquanto apelo torna a aparecer na literatura contemporânea. Escrever, e sobretudo publicar uma obra, é apelar para o público, é romper, por um gesto unilateral, a relação de indiferença entre Si próprio e os Outros" (2009, p. 294-5). O crítico complementa dizendo que

\footnotetext{
O escritor romântico procurou por muito tempo convencer a sociedade de que lhe dava mais do que aquilo que dela recebia. Desde o fim do século XIX, toda ideia de reciprocidade, mesmo imperfeita, no relacionamento com o público se tornou insuportável. O escritor ainda se faz editar mas para esconder esse crime, faz de tudo para impedir que se leiam seus livros. Por bastante tempo alegou que falava tão somente consigo mesmo, e alega agora que fala para não dizer nada.

Ele não está dizendo a verdade. O escritor fala para nos seduzir, como no passado. Ele ainda fica à espreita da admiração em nosso olhar que seu talento nos inspira. [...] Precisa primeiro se convencer de que não está tentando nos agradar. (GIRARD, 2009, p. 294-5)
}

É interessante notar a semelhança entre o que defende Girard e a reflexão de Ricoeur ao sustentar que "a retórica da ficção põe em cena um autor implicado que, por manobra de sedução, tenta tornar o leitor idêntico a ele mesmo" (2010,p. 306, grifo do autor).

Para Girard (1964), o desejo humano não é autônomo, mas mediado por um Outro. A ligação entre os personagens do romance, segundo o crítico, pode ser transposta por meio de uma relação triangular. Em um romance como Madame Bovary ${ }^{14}$, por exemplo, Emma deseja uma vida diferente da que tem, devido ao modelo sugerido a ela pela leitura de romances. Suas aventuras amorosas não resultam de um desejo espontâneo, já que Emma quer copiar o modelo fornecido pelas heroínas românticas dos livros que lê. Estabelece-se então uma relação triangular: Emma é o sujeito desejante que, pela leitura dos romances, tem como modelo as heroínas românticas e seus ideais de vida e, assim, acaba por almejar esse modo de vida para si, que constituirá o objeto da relação. No entanto, Emma

\footnotetext{
14 Esboçamos neste ponto um brevíssimo resumo da relação mimética triangular, conforme concebida por Girard (1964) em Mentira romântica e verdade romanesca.
} 
desejará, em última instância, uma outra vida, um outro ser. Esse seu desejo, porém, estará fadado à frustração, pois ela não pode deixar de ser quem ela é. Girard chama a isso de desejo metafísico, já que o desejo é pautado em um estado ou, mais especificamente, em outro ser e não visa um objeto físico. Como bem explica Andrade:

Desenvolve-se nos personagens o que Girard denomina um “mal ontológico”. O herói romanesco sente uma carência de ser e crê que o mediador possui tal sentido ontológico. Imitando seu mediador e seus desejos, tentará apropriar-se do ser do Outro, e pretenderá aliviar assim o vazio que sente em seu interior”. (ANDRADE, 2011, p. 58)

Ainda acerca dessa relação triangular e o "desejo metafísico", é igualmente elucidativa a análise que Girard faz de um aspecto da obra Em busca do tempo perdido, de Marcel Proust:

Seriam os simbolistas excessivamente tímidos? Teremos que negar por completo o papel do objeto e proclamar a autonomia absoluta do desejo? Tal conclusão agradaria aos críticos solipsistas. Infelizmente o narrador não inventou a Berma. A atriz é efetivamente real; ela existe fora do Eu que a deseja. Não se pode pois abrir mão de um ponto de contato com o mundo exterior. Porém não é um objeto e sim uma outra consciência que garante esse contato. É um terceiro que indica ao narrador o objeto que ela vai pôr-se a desejar com paixão. Marcel sabe que Bergotte admira a grande atriz. Bergotte goza, junto a ele, de um imenso prestígio [...]. (GIRARD, 2009, p. 53)

Como vemos na passagem acima, Girard sugere que o desejo do narrador por Berma está pautado em sua admiração pela figura de Bergotte. Transpondo a análise girardiana para a obra de Gide, podemos pensar na leitura do romance e do diário de Os moedeiros falsos como mediadora da relação entre autor e leitor. Trata-se de uma relação mimética que, na obra de Gide, se potencicializa devido aos efeitos gerados pela construção narrativa, gerando o que Girard chama de "desejo metafísico" no leitor.

O leitor passa a desejar tendo o Outro como mediador de seu desejo, conceito chave para a teoria girardiana. Esse outro que serve de modelo para o leitor não é mais um personagem de romance, com o qual o leitor romanticamente se identifica, mas sim o autor, ou a "figura do autor", construída em torno do "mito do escritor". Como nota Anspach (2012, p. 78), “a variedade dos desejos possíveis é tão grande como a variedade dos mediadores possíveis" e, para ilustrar essa infinidade de possibilidades, o autor cita o exemplo da relação entre o narrador de Em busca do tempo perdido e sua mãe:

Aqui, o desejo do filho pela mãe, em vez de surgir espontaneamente, é atiçado pela dor que ele sente por ser excluído de uma noite encantadora reservada aos adultos. Ao recusar-se a ele, a mãe de Marcel inflama sua paixão por ela, da mesma forma que a coquete inflama sua paixão do amante ao rejeitar os avanços deste. Mãe e filho formam um triângulo insólito em que ela ocupa simultaneamente as posições de objeto e de rival. (ANSPACH, 2012, p. 78) 
Em termos girardianos, o leitor de Gide passaria a ter o autor como modelo e como objeto de desejo, tendo em vista a construção, por meio da leitura do romance, de uma imagem do escritor, de um "mito do escritor". Como podemos observar, a leitura do romance e do diário Os moedeiros falsos mostra a consciência de um autor voltada a seu leitor, transposta na própria estrutura do romance. Essa postura pode se relacionar a um fenômento ainda hoje bastante comum e que relatamos inicialmente: o aumento constante do interesse de leitores pela vida e pela imagem dos escritores.

Esse "fenômeno" do interesse pela figura do escritor permanece bastante atual. No Brasil, por exemplo, vemos o crescimento constante de "oficinas literárias" que, em sua maioria, oferecem cursos ministrados por escritores. O constante aumento da procura por cursos, oficinas e palestras proferidos por escritores nos mostra o interesse dos leitores em saber o que o autor tem a revelar. Não é apenas a obra que interessa, mas também a sua vida, suas paixões, sua visão de mundo. Os leitores passam a demonstrar sua vontade de, mediados pela figura do admirado escritor, tornarem-se, eles também, escritores.

Além disso, o leitor contemporâneo, pela possibilidade de uma participação ativa em uma leitura, passa a se ver como re-criador da obra, podendo ele também se tornar, de alguma forma, criador. Dessa forma, acreditamos que a maneira como Gide seduz seu leitor, por meio das reflexões que permeiam a própria construção narrativa de $O s$ mo- $^{-}$ edeiros falsos, permite uma participação ativa do leitor que, desconfiado, sente-se desafiado e perturbado pela obra. A leitura do romance conjuntamente com o Diário dos Moedeiros Falsos desestabiliza a todo momento o horizonte de expectativas do leitor. Essa participação ativa se dá, em parte, pela possibilidade de uma leitura que questiona os limites entre ficção e realidade, permitindo assim uma reconfiguração da relação entre leitor e autor.

As reflexões acerca do papel do leitor, cujos desenvolvimentos atuais se devem aos primeiros estudos teóricos da estética da recepção, permitem uma compreensão do papel da leitura para a interpretação de uma obra e nos auxiliam também a encontrar convergências com a teoria e crítica literária contemporâneas, como é o caso da teoria mimética de René Girard.

A fim de concluir, é possível ver como Os moedeiros falsos de André Gide, aliado à leitura do Diário que nos fornece a gênese do romance, permite novas possibilidades de leitura e interpretação, possíveis graças a um elaborado trabalho entretido pelo autor. Por meio desse trabalho de construção, Gide favorece a reflexão sobre a criação literária, ligada às relações entre vida e obra, realidade e ficção. A atualidade dessa obra se mantém, pois, à medida que continua a permitir uma relação da escritura com o crescente interesse nos processos de criação que prefiguram o mito em torno do escritor.

\section{Referências Bibliográficas}

ANDRADE, Gabriel. René Girard: um retrato intelectual. São Paulo: É Realizações, 2011. ANSPACH, Mark R. Édipo Mimético. São Paulo: É Realizações, 2012.

BARTHES, Roland. “Notas sobre André Gide e seu Diário”. In: Inéditos - vol. 2: crítica. São Paulo: Martins Fontes, 2004. 
COMPAGNON, Antoine. O demônio da teoria: literatura e senso comum. Belo Horizonte, Editora UFMG, 2010

GIDE, André. Les Faux-Monnayeurs. Paris: Gallimard, 2009c. . Journal des Faux-Monnayeurs. Paris: Gallimard, 1934. . Diário dos moedeiros falsos. São Paulo: Estação Liberdade, 2009a. . Os moedeiros falsos. São Paulo: Estação Liberdade, 2009b.

GIRARD, René. Mentira romântica e verdade romanesca. São Paulo: É Realizações, 2009. GOULET, Alain. André Gide, Les Faux-Monnayeurs: mode d'emploi. Paris: Sedes, 1991 HUBIER, Sébastien. Littératures Intimes: les expressions du moi, de l'autobiographie à l'autofiction. Paris: Armand Colin, 2005.

JAUSS, H. R. et al. A literatura e o leitor: textos da estética da recepção. In: LIMA, Luiz Costa (org). Rio de Janeiro: Paz e Terra, 1979.

KLINGER, Diana. Escritas de si, escritas do outro: o retorno do autor e a virada etnográfica. Rio de Janeiro: 7 Letras, 2007.

L'AUTOFICTION: UNE RÉCEPTION PROBLÉMATIQUE. www.fabula.org/forum/colloque99/208.php. Acesso em: 15 maio 2012.

MANGUEL, Alberto. Uma história da leitura. São Paulo: Companhia das Letras, 2010.

MILLER, Henry. Os livros da minha vida. Lisboa: Antígona, 2006.

PAMUK, Orhan. O romancista ingênuo e o sentimental. São Paulo: Companhia das Letras, 2012. RICOEUR, Paul. Tempo e narrativa, vol. 3 - o tempo narrado. São Paulo: WMF Martins Fontes, 2010.

TODOROV, Tzvetan. A literatura em perigo. Rio de Janeiro: Difel, 2010.

ArTigo RECEBIDO EN: 19 ago. 2012

ArTigo ACEITO EM: 12 set. 2012

REFERÊNCIA ELETRÔNICA: BEZERRA, Isabelle Santos. Entre a sedução e a desconfiança: o jogo do autor e do leitor em Les Faux-monnayeurs de André Gide. Revista Criação \& Crítica, n. 9, p. 95-110, nov. 2012. Disponível em: <http://www.revistas.usp.br/criacaoecritica>. Acesso em dd mmm aaaa. 